\title{
INTERVIEWS
}

\section{Valentin G. Nemirovsky's Interview with Jan T. Toshchenko}

Interviewer: Dr. Sci. (Soc.), Professor, Leading Research Associate, Department of General and Economic Sociology, Tyumen State University; Editor-in-Chief of the Siberian Socium Journal

Interviewee: Dr. Sci. (Philos.), Professor, Corresponding Member of the RAS, Moscow; Editor-in-Chief of the Sotsiologicheskie Issledovaniia Journal

DOI: $10.21684 / 2587-8484-2017-1-1-6-8$

V. Nemirovsky: Professor Toshchenko, in your interview with Boris Z. Doktorov you said that "to the students' questions what made me a sociologist, I answered: Siberia"1. Can modern Siberia, in your opinion, encourage an active young person to choose the profession of sociology?

J. Toshchenko: When I say that Siberia made me a sociologist, I mean that, since my participation in the construction of the Abakan-Taishet railway, and all the subsequent years of my life in Khakassia and the Krasnoyarsk Krai, I have constantly wondered about one question: why, despite the large-scale development of new cities and enterprises, have so many social problems not been solved? Why are there problems with housing, household equipment, people's daily needs, the work of cultural and educational institutions, lack of recreational opportunities? To answer this question, I entered Irkutsk Institute of National Economy, but soon realized that I was looking for answers in the wrong direction.

It was the desire to find an answer to this question that helped me choose my field of interest at postgraduate school and then my job at Krasnoyarsk University. There I formed a sociological laboratory, where together with younger col-

\footnotetext{
J. T. Toshchenko: "Sociology was first revived in Russia as a political showcase." In: Doctorov B. Z. 2014. Besedy s sotsiologami chetyriych pokoleniy [Conversations with sociologists of four generations], vol. 2 of Sovremennaya rossiiskaya sotsiologiya: istoriko-biograficheskie poiski [Modern Russian Sociology: Historical and Biographical Search]. Edited by E. I. Grigoriev. P. 476. Moscow.
}

leagues (who came from various sectors of economy and culture) we looked for solutions to the social problems of the residents and workers of the Krasnoyarsk Krai. I would like to emphasise with this that it was the desire to understand the life in Siberia, the issues of a man's destiny, that urged me to look for answers.

Now life in Siberia is different. The problems are different too, though equally numerous and no less important. They include the emergence of new types of unemployment (particularly as a result of closing businesses in single-industry towns and settlements); a new structure of employer-employee relations; the development of new forms of inequality, not only in the material sense, but also inequality in everyday life, education and culture. We also should not forget about migration problems (the out- and inflow of the labour force), about experiments in education and health which completely ignore the specificity of the Siberian territories. And so on and so forth. Young people who wish to choose sociology as a profession have an infinite field where they can fulfil themselves looking for the answers to these questions.

One should simply take great interest in the field in which one works, and have the desire to find the truth there.

V. Nemirovsky: Professor Toshchenko, you were among the first scientists who conducted sociological research in the 1960s in the Krasnoyarsk Krai, therefore, you can be rightfully regarded as one of the founders of Siberian sociology. Is it possible, in your opinion, to talk about the specificity of Siberian so- 
ciety compared to other societies across Russia? If yes, how does it reveal itself?

J. Toshchenko: Certainly, there is a great specificity of Siberian society. In the previous answer, I mentioned some of its typical features. Yet, apart from them there are many others. It is the development of new territories, related not only to oil and gas. It is the emergence of new forms of work and everyday life. Ethnonational and religious problems manifest themselves in a new way (compared to the Soviet times). A lot of work should be done to improve regional infrastructure and transportation especially. When I worked in Khakassia, the infrastructure shortcomings were compensated by regular An-2 flights to almost every corner of the region. What is now offered?

V. Nemirovsky: For many years, you have been editing the most significant Russian sociological journal. Could you please name the most interesting publications devoted to the issues of Siberia?

J. Toshchenko: Siberian sociologists have regularly presented research results in the journal Sotsiologicheskie Issledovaniia. I will name the most striking and significant ones: S. I. Grigoriev and L. G. Guslyakova (as well as Yu. E. Rastov previously) represent the Altai Krai; G. F. Kutsev and V. V. Gavrilyuk represent Tyumen; V. G. Nemirovsky, A. M. Gendin, D. D. Nevirko, V. E. Shinkevich (as well as V. H. Belenky and M. I. Sergeev previously) represent Krasnoyarsk; I. I. Osinsky represents Buryatia. Sociologists from Novosibirsk have published materials devoted to the sociology of the village; their brightest representatives are O. V. Nechipurenko, Z. I. Kalugin, O. P. Fadeyeva. O. A. Karmadonov (Irkutsk) and D. V. Trubitsin (Chita), who have published interesting articles on the issues of theoretical sociology. At the same time we give young sociologists an opportunity to express their views.

Unfortunately, articles sent to us for publication are not devoid of such common drawbacks as: a) materials that look like reports, whereas a report is the initial form of analysis; a report is not yet an article and it requires scientific generalization that enriches sociology as a science; b) some articles are of a very narrow local character, whereas sociological research should present interest for wider audiences, including various Russian and foreign readers. More detailed requirements for publication can be found in the articles that I published in the journal Sotsiologicheskie Issledovaniia "On Academic and Methodological Culture" (Sotsiologicheskie Issledovaniia 2014, no 1) and "On the Quality of Academic Publications" (Sotsiologicheskie Issledovaniia 2015, no 1).

V. Nemirovsky: To what issues of modern Siberia should our new journal pay particular attention?

J. Toshchenko: I am very happy that your journal has been created. Siberia has long needed such a scientific journal. Many Siberian universities have tried to establish the publication of sociological research, but they have mostly analysed the problems of their regions. Therefore, the efforts that Tyumen State University has made to establish a Siberian journal should be welcomed, and I would like to wish you success in uniting the intellectual and creative forces of Siberian sociologists. As for the issues the new journal should pay attention to, I have already answered this in the response to the first and second questions. Of course, I would like to advise you to develop some already successfully established areas which produce results worthy of attention and support.

V. Nemirovsky: What methods and approaches are relevant for the study of the Siberian regions?

J. Toshchenko: When it comes to the methods of modern sociology, I often turn to the existing experience of Russian scholars. In my view, a model of comprehensive, in-depth and thorough analysis of sociological issues is presented in the monograph by A. M. Bolshakov The Village (1917-1927) (Moscow, 1928). This work was reviewed by G. A. Tsvetkova in the journal Sotsiologicheskie Issledovaniia (no 12 in 2016). What makes this work stand out? It is a specimen of monographic writing. From the methodological viewpoint, it employs a wide variety of methods: the author begins his research reviewing the history of the Tver province villages; then he analyses national, regional, and county statistical data regarding the economy and other aspects of the life of the peasants in these villages. The researcher studies a wide range of official documents on the national scale as well as personal meetings with the 
villagers; he analyses publications in national, regional and local periodicals, reviews peasant households' financial documentation, collects material on the activities of the Bolshevik and Komsomol organisations, analyses data on measures against illiteracy. Furthermore, he conducts a series of opinion polls involving young people and students; he holds interviews with directors and specialists; finally, he even analyses local songs and rhymes. Thus, we see a remarkable result that has stood the test of time. We see a detailed and vivid picture of the village belonging to the first decade of the Soviet era in all its complexity and diversity. That is a benchmark which all research should aspire to. Of course, one should also avoid a common trap many sociologists tend to fall into - "we conducted a survey, we received the following results".

In summary, I sincerely would like to wish the new journal to occupy a firm academic and civic position, and to work tirelessly for the unity of Siberian sociologists. I also wish Siberian sociologists to reach results compatible with the results of studies in Russian and international sociology. I am sure your journal has a future.

V. Nemirovsky: Thank you very much, Professor Toshchenko, for your extended answers and warm wishes to our journal. We will work hard to live up to your expectations! 